\title{
THE AETIOLOGY AND TREATMENT OF URINARY CALCULUS
}

\author{
A. Hodgrinson, Ph.D., F.R.I.C. \\ Senior Biochemist, Medical Research Council Unit for Metabolic Disturbances in Surgery \\ The General Infirmary at Leeds
}

\begin{abstract}
DESPITE its antiquity, the mechanism of urinary calculus formation remains obscure, but recent studies have provided a better understanding of the many factors that are involved and some of these are considered in the present review. Studies in this department have been concerned mainly with stones consisting of calcium oxalate or a mixture of calcium oxalate and calcium phosphate. These are the commonest types of stones in Western countries (Murphy and Pyrah, 1962; Prien, 1963).
\end{abstract}

\section{Urinary excretion of calcium, inorganic phosphate and oxalic acid}

Hypercalciuria occurs in approximately onethird of patients with calcium-containing renal stones (Hodgkinson and Pyrah, 1958; Litin, Diessner and Keating, 1961). A significant metabolic cause for the hypercalciuria can be found in about $25 \%$ of these cases, the principal causes being primary hyperparathyroidism, bone disease, immobilisation, renal tubular acidosis, sarcoidosis or an excessive intake of milk, alkalis or vitamin D (Harrison, 1959; Litin and others 196r ; Hodgkinson and Pyrah, 1962). In these cases it is usually possible to reduce calcium excretion to normal levels by appropriate treatment. In the remaining $75 \%$ of cases, however, the cause remains obseure and the term 'idiopathic high urine calcium' was introduced by Flocks (1940) to describe this condition. There is no established treatment for idiopathic hypercalciuria at present though calcium excretion can be reduced to normal or near-normal levels by a low calcium diet (Hodgkinson and Pyrah, 1958; Harrison, I959), oral sodium phytate (Henneman, Benedict, Forbes and Dudley, I958), diuretic sulphonamides (Lichtwitz, Palier, de Seze, Hioco and Miravet, 196I) or neutral sodium phosphate (Fig. 2).

Although the phosphate radicle is a common constituent of renal calculi, no significant abnormality has been found in the excretion of inorganic phosphate (Cottet and Vittu, 1955; Hodgkinson and Pyrah, 1958). Reduction of urinary phosphate by low phosphorous diets and oral aluminium hydroxide, however, will sometimes prevent the recurrence of phosphate-containing stones (Shorr and Carter, I950; Pyrah, Raper and Smith, 1956).
We have found that patients with 'pure' calciurf phosphate stones are most likely to benefit from this treatment.

The daily excretion of oxalic acid is withif normal limits in the majority of patients with urinary calculi (Hodgkinson, 1958; Dempsey Forbes, Melick and Henneman, I960), but markedly increased excretion is observed occasion ally in children and young adults having a histor of recurring calcium oxalate stones. This condition has been studied extensively by Archer and his colleagues who introduced the term 'primarg hyperoxaluria' (Archer, Dormer, Scowen and Watts, 1958). The nature of the defect is still no fully understood but recent studies suggest that there is a genetically-determined abnormality in the metabolism of glyoxylic or glycollic acid whigeto results in an increased production of endogens oxalic acid (Frederick, Rabkin, Richie and Smâh 1963). There may be more than one defect, how ever, since studies in this laboratory have reveale a markedly increased renal clearance of oxalie acid (Zarembski and Hodgkinson, r963). There i 8 no satisfactory treatment for this condition at pres ent.

Although the majority of patients with urinary calculi have a normal daily excretion of oxalic aci when receiving a normal controlled diet, moderately increased excretion is observed in some adult patients with recurrent calcium oxalate stones(Hodgkinson, 1958; Ludwig, 1963). It is not yeep. clear whether this represents a mild adult form of primary hyperoxaluria or a completely different ætiology.

Most of the oxalic acid excreted in the urines appears to originate from metabolic processes in the body rather than from the diet. Nevertheles it would seem prudent for patients with calcium? oxalate stones to avoid high oxalate-containing foods such as rhubarb, spinach and beet. We have् found that tea is the major source of oxalic acid in English diets (Zarembski and Hodgkinson, 1962) but there is no evidence that tea drinking con tributes to oxalate stone formation.

Various attempts have been made to reduceo oxalate excretion in patients with oxalate stones. particularly those with primary hyperoxaluria Archer and others (1958) reported a decrease in 
oxalate excretion in primary hyperoxaluria when oral sodium benzoate was given to deplete the glycine pool but others have found that the effect is only slight (McLaurin, Beisel, McCormick, Scalettar and Herman, 196r; Marshall and Horwith, 1959). Hammarsten (1956) reported that the oral administration of magnesium oxide to twelve adults, four of whom had passed calcium oxalate stones, resulted in an appreciable reduction in oxalate excretion, but we have been unable to confirm this (Pyrah, Anderson, Hodgkinson and Zarembski, 1959). Experimental pyridoxine deficiency has been found to cause oxalate nephrocalcinosis and lithiasis in the cat and rat (Gershoff, Faragalla, Nelson and Andrus, 1959; Andrus, Gershoff and Faragalla, 1959) but pyridoxine supplements have proved to be ineffective in reducing urinary oxalate in man (Daniels, Michels, Aisen and Goldstein, 1960; McLaurin and others, 1961).

Relatively little is yet known about the endogenous sources of urinary oxalate. Investigations of oxalate metabolism have been hampered in the past by the lack of an accurate micro-method for determining oxalic acid in biological materials. We have recently developed a spectrophotofluorimetic method for determining oxalic acid which promises to overcome this difficulty (Zarembski and Hodgkinson, to be published).

\section{Solubilizing substances in urine}

Since the excretion of stone-forming substances (calcium, phosphate and oxalate) is frequently normal in patients with renal calculi, attention has been directed to the substances which influence the solubility of calcium salts in the urine.

It is well known that normal urine will maintain higher concentrations of calcium salts in solution than will water. This property is due partly to the non-specific 'salting in' effect of the urinary electrolytes (sodium, potassium, chloride, sulphate) and also to the presence of various organic constituents, for example, urea, glucuronides, ammonium chondroitin sulphate and the salts of several organic acids. Neuberg (1916) introduced the term 'hydrotropy' to describe the solubilizing effect of these organic constituents but the mechanism is still not understood. The chief interest in hydrotropy stems from the work of Prien and Walker (I956) who recommended the oral administration of salicylates in order to increase the excretion of glucuronide. The value of this treatment is doubtful, however, since Vermeulen, Finlayson and Chapman (1957) found that significant solubilizing of calcium salts requires a much higher concentration of glucuronide than can be achieved by salicylate therapy. Moreover, clinical trials with salicylates have generally been disappointing (Abrams, r957; Comarr and Carne, 1958).

Miller, Vermeulen and Moore (1958) concluded that the observed solubility of calcium oxalate in urine could be adequately explained by the 'salting-in' effect of the urinary electrolytes and the formation of complex ions with magnesium and citrate. In the case of calcium phosphate there appeared to be an additional dialysable factor which was not identified (Vermeulen, Lyon and Miller, 1958).

The role of magnesium as a solubilizing factor in urine has been recognized for many years but its importance in calculus formation is still uncertain. Hammarsten (1956) suggested that oxalate stone formation may be due to a deficiency of urinary magnesium but this has not been confirmed by subsequent studies (Desgrez, Thomas, Thomas and Rabussier, I962; Hodgkinson, 1963). The efficacy of oral magnesium supplements in preventing the recurrence of calcium phosphate and calcium oxalate stone is being investigated by Prien, Gershoff and Andrus (1962) and Mukai and Howard (1963) but the results of these studies are not yet available.

Citric acid is present in normal urine at molar concentrations comparable to that of the calcium present and it is well recognized that this acid willo bind calcium ions with the formation of a soluble, slightly ionized complex. A reduced excretion of citrate has been observed in some patients with urinary lithiasis and various measures to increase citrate excretion have been investigated, for example alkalinizing salts, œstrogens and fluoroacetate. Conway, Maitland and Rennie (1949) suggested that the rationale for such measures required reconsideration since hypocitricuria appeared to be due to post-renal destruction of citric acid by organisms infecting the urinary tract, rather than to a deficiency of citric acid excretion by the kidney. However, Scott, Huggins and Selman (1943) were unable to find extensive evidence of urinary tract infection in their patients and subsequent studies indicate that the primary cause of hypocitricuria is impairment of renal glomerular function (Hodgkinson, 1962; Taupitz and Gaca, 1962). In such cases it is unlikely that measures to increase the excretion of citrate would be of significant value in preventing the recurrence of stone.

Impairment of renal function is not the only cause of hypocitricuria however. At least two 'metabolic disorders' are known in which calculus formation is associated with hypocitricuria in the absence of glomerular damage, namely, renal tubular acidosis, and following prolonged ingestion of acetazoleamide (Gordan and Sheps, 1957; Dedmon and Wrong, 1962). In these cases, 
CITRIC ACID/CALCIUM RATIOS IN URINE

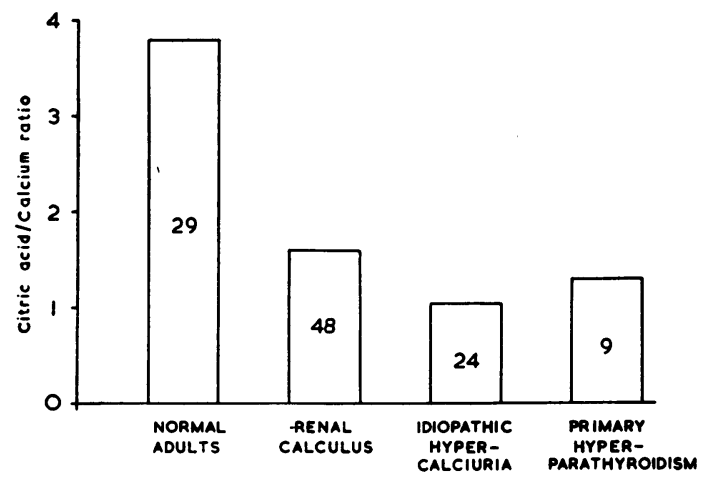

FIG. 1.-The ratio of urinary citric acid to calcium (mg. per $24 \mathrm{hr}$.) in normal adults and in patients with renal calculus. The figures in each column denote the number of individuals in the sample

treatment with alkalis and potassium salts is of considerable therapeutic value.

Although urinary citrate has received considerable attention, its importance in stone formation is still not very clear. Nordin (1959) observed that hypocitricuria is not such a frequent or striking finding in patients with renal calculus as has been suggested by previous workers and this has also been the writer's experience (Hodgkinson, I962). The solubilizing effect of individual urinary constituents cannot be considered in isolation however. For example, Walser (196r) reported that in biological fluids, citrate has an equal or greater affinity for magnesium than it has for calcium. An increase in the concentration of citrate will therefore reduce the concentration of magnesium ions available for complexing with calcium oxalate. Conversely, an increase in the concentration of magnesium will reduce the amount of citrate available for complexing with calcium (Johnson, 1959).

The absolute amount of citrate in the urine may be of less importance than the ratio of citrate to calcium. We have found considerable differences in the citric acid/calcium ratio between normal adults and patients with renal calculi; this was particularly marked in the patients with hypercalciuria although the concentration of citrate was frequently within normal limits (Fig. I).

Raaflaub (1960) reported that from 33 to $58 \%$ of urinary calcium is normally in a 'free' or ionized form, the remainder being bound, mainly with citrate. The low citrate/calcium ratios in urine from patients with renal calculi suggest that the proportion of free to total calcium is higher than normal and this is supported by the work of Nordin and Tribedi (1962) who reported a significantly higher percentage of ionized calcium in the urine of stone-forming patients, compared with normal subjects. Others, however, have failed to detect any divergences from normal (Vermeulen, Miller and Chapman, 1956; Thomas and Howard, 1959; Hunt and King, 196r) and further confirmatory studies appear to be desirable.

The ratio of urinary calcium to phosphate may also be a significant factor although opinions differ as to the nature of this effect. For example, Gill, Finlayson and Vermeulen (1959) reported that experimental calculus formation in rats could be prevented by adding calcium to the diet. The additional calcium caused a marked increase in urinary calcium but phosphate excretion was reduced. The authors suggested that stone formation does not occur below a critical concentration of phosphate, even if the concentration of calcium is relatively high. Neuman (1962), however, reported that the tendency for calcium pinosphate to precipitate increases as the calcium/ phosphate molar ratio approaches that observed in octocalcium phosphate or apatite; this value is approximately $\mathrm{I} .7$.

\section{Supersaturation, nucleation and crystal poisons}

There is increasing evidence that, despite it $\vec{\theta}$ 'supersolubility', urine is usually supersaturate $\$$ with respect to apatite and other stone-forming substances (Yarbro, 1958; Neuman, I962; Ver? meulen, Lyon and Gill, 1964). Under conditions of supersaturation a solute will precipitate spontaneously from solution, the rate of pre- $\mathbb{\perp}$ cipitation or crystallization being proportional to $\overrightarrow{\vec{P}}$ the degree of supersaturation. The rate of $\frac{0}{3}$ crystallization may be very slow if there is only a slight degree of supersaturation ('metastable' supersaturation) but the process can be accelerated by introducing a small crystal of the solute; this 3 . is referred to as 'seeding', or 'nucleation'. Crystallization from the 'metastable' supersaturated $\stackrel{3}{3}$. state can also be accelerated by particles having a $\stackrel{8}{\circ}$ different composition to the solute and many microscopic particulate bodies within the urinary 을 tract may be potential nucleators.

One of the main reasons why calculi are not more frequent appears to be that urine contains $\bar{N}$ crystal 'poisons' that will prevent nucleation and 0 subsequent crystal growth. An example of the $N$ practical application of crystal poisons is found in $\underset{\omega}{N}$ the use of organic or inorganic polyphosphates to 0 prevent boiler-scale production. The influence 0 of these compounds on the mineralization of bone $\frac{}{\Phi}$ has been recognized within recent years. For $\stackrel{\mathscr{?}}{+}$ example, $\alpha$-glycerophosphate was found to inhibit $\urcorner$ the mineralization of powdered bone ash ( $\mathrm{Di} \stackrel{\mathrm{O}}{\mathrm{P}}$ Stefano, Mulryan and Neuman, 195I) and 
certain phosphopeptides and inorganic polyphosphates will inhibit the mineralization of rachitic rat cartilage (Howard, Thomas, Mukai, Johnston and Pascoe, r962; Thomas, Bird and Tomita, 1963).

The possible role of phosphate compounds in preventing urinary stone formation has been investigated by a number of workers (Howard, 1962; Neuman, 1962; Fleisch and Bisaz, 1962; Thomas, Bird and Tomita, 1963). Fleisch and Bisaz (1962) concluded that normal urine contains a number of inhibitors to hydroxyapatite precipitation, one of the more important being inorganic pyrophosphate. In a subsequent paper, however, the authors reported that urinary pyrophosphate levels are appreciably higher in normal men than in normal women (Fleisch and Bisaz, 1963). Since calculus formation occurs more frequently in men than in women, pyrophosphate excretion might be expected to be lower in the former than in the latter. The significance of pyrophosphate in relation to calculus formation therefore remains uncertain.

Studies by Howard (1962) on the mineralizing propensity of rachitic rat cartilage revealed that this preparation would calcify when incubated in urine from stone-bearing patients but it failed to calcify in normal urine. The oral administration of neutral sodium phosphate $\left(\mathrm{Na}_{2} \mathrm{HPO}_{4}\right)$ to patients with urinary calculi resulted in the production of urine in which cartilage failed to calcify, suggesting that phosphate supplementation might be of value in preventing the recurrence of urinary calculi. Preliminary trials in this laboratory and elsewhere indicate that this treatment is of considerable value in selected patients but further studies are necessary before any definitive conclusions can be reached.

The mechanism by which phosphate supplementation inhibits stone formation is still not resolved. The effect of phosphate deprivation and supplementation on the urinary excretion of calcium, magnesium, phosphate, citrate and pyrophosphate was observed in four male patients with calcium-containing renal calculi who were maintained on controlled normal diets and the results are summarized in Fig. 2. The patients were observed for a period of 10 days on each regime and the experimental points shown in Fig. 2 represent the mean values for the four patients.

Phosphate supplementation resulted in a substantial increase in urinary phosphate, pyrophosphate, and citrate, and a decrease in urinary calcium. Phosphate deprivation resulted in a reduced excretion of phosphate, pyrophosphate and citrate and an increased excretion of calcium. Magnesium excretion was not altered to any

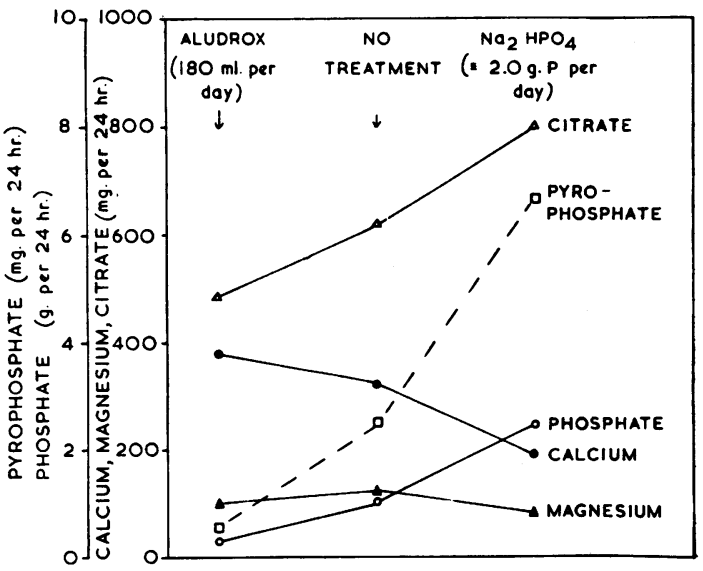

FIG. 2.-The effect of oral aluminium hydroxide and neutral sodium phosphate on the urinary excretion of calcium, magnesium, phosphate, pyrophosphate and citrate in four men with renal calculus.

appreciable extent by either phosphate supplementation or deprivation.

The significance of these results in relation to calculus formation is not yet clear. Although the product $(\mathrm{Ca} \times \mathrm{P})$ increased during phosphate supplementation, this, presumably undesirable, effect may be compensated by the increase in citrate and pyrophosphate excretion. Conversely, the substantial decrease in $-(\mathrm{Ca} \times \mathrm{P})$ which occurred during aluminium hydroxide administration may be nullified by the simultaneous fall in citrate and pyrophosphate excretion. It may be necessary to consider, not only the product $(\mathrm{Ca} \times \mathrm{P})$, however, but also the ratio of calcium to phosphate in the urine (Gill, Finlayson and Vermeulen, 1.959; Neuman, 1962).

\section{Conclusions}

Investigations in this laboratory have been based on the hypothesis that calculus formation is primarily a process of crystallization from supersaturated solutions rather than one of adsorption on a specific protein matrix, as has been postulated by Boyce and his colleagues (Boyce and King, 1963). That crystallization is the primary factor is strongly suggested by the recent studies of Vermeulen, Lyon and Gill (1964). These authors produced artificial concretions which closely resembled urinary calculi by immersing a rotating wire loop in normal urine for several days and slowly adding the appropriate stone-forming elements.

If the above hypothesis is correct then the factors of primary interest in urinary stone formation are those responsible for supersaturation, nucleation and crystal poisoning. Much remains 
to be learnt about these various factors, their inter-relationships, and their relative importance.

The significance of the urinary colloids (proteins, muco-proteins and polysaccharides) in calculus formation is still not clear but it is probable that they play an important secondary role in binding crystalline precipitates to form a non-friable calculus. Since time is an important factor in crystal growth such non-specific binding by⿳亠㐅冋 proteins would increase the chances of stone 3 growth and retention within the upper urinary $\stackrel{\mathbb{2}}{\stackrel{2}{2}}$ tract.

The author wishes to thank Dr. F. W. Heaton, Mr, N. A. Edwards and Mr. R. G. G. Russell for the data contained in Figure 2.

\section{REFERENCES}

Abrams, M. (1957): Unfavourable Results of Acetyl-salicylic Acid in the Treatment of Recurrent Urolithiasis, $\mathcal{F}$. Urol. $\stackrel{\oplus}{\rightarrow}$ (Baltimore), 77, 372.

Andrus, S. B., Gershoff, S. N., and Faragalla, F. F. (1959): Calcium Oxalate Renal Calculi Induced in Rats by $\overrightarrow{-}$ Vitamin $\mathrm{B}_{6}$ Deficiency, Amer. F. Path., 35, 671.

Archer, H. E., Dormer, A. E., Scowen, E. F., and Watts, R. W. E. (1958): The Etiology of Primary Hyperoxaluria. Brit. med. F., i, 175 .

Boyce, W. H., and KING, J. S. (1963): Present Concepts Concerning the Origin of Matrix and Stones, Ann. N.Y. 3 Acad. Sci. 104, 563 .

Comarr, A. E., and CARne, H. O. (1958): Acetyl-salicylic Acid and Salicylamide: Effect on Renal Calculosis in $\overrightarrow{0}$ Patients with Spinal Cord Injury, $\mathcal{F}$. Urol. (Baltimore), 79, 911 .

Conway, N. S., Maitland, A. I. L., and Rennie, J. B. (1949): The Urinary Citrate Excretion in Patients with Renal $\rightarrow$ Calculi, Brit. F. Urol., 21, 30.

Cottet, J., and Vittu, Ch. (1955): Calcium Urinarire et Lithiasis Urinaires, Presse méd., $63,878$.

Daniels, R. A., Michels, R., Aisen, P., and Goldstein, G. (ig6o): Familial Hyperoxaluria, Amer. F. Med., 29, 820.

Dedmon, R. E., and Wrong, O. (1962): The Excretion of Organic Anion in Renal Tubular Acidosis with Particular Reference to Citrate, Clin. Sci., 22, 19.

Dempsey, E. F., Forbes, A. P., Melick, R. A., and Henneman, P. H. (1960): Urinary Oxalate Excretion, Metabolism, 9, 52.

Desgrez, P., Thomas, J., Thomas, E., and Rabussier, H. (1962): Facteurs Influencant l'equilibre Urinaire dans la $\stackrel{\widehat{\rho}}{\supset}$ Lithiase Calcique. Proc. Symp. Internat. sur la Lithiase Calcique, Vittel, 4, II, 189.

Di Stefano, V., Mulryan, B. J., and Neuman, W. F. (r95I): The Surface Chemistry of Bone. III. Observations on the Role of Phosphatase, f. Biol. Chem., r93, 227.

Fleisch, H., and Bisaz, S. (1962): Isolation from Urine of Pyrophosphate, a Calcification Inhibitor, Amer. $\mathcal{J}$. Physio 203,671 .

Fleisch, H., and Bisaz, S. (1963): Die Pyrophosphatausscheidung im Harn beim gesunden Menschen, Hel $\vec{v}-$ physiol. Pharmacol. Acta, 21, 88 .

Flocks, R. H. (r940): Prophylaxis and Medical Management of Calcium Urolithiasis: Role of Quantity and Precipitability of Urinary Calcium, $\mathcal{F}$. Urol. (Baltimore), 44, I83.

Frederick, E. W., Rabkin, M. T., Richie, R. H., and SMITH, L. H. (I963): Studies on Primary Hyperoxaluria. I In $\varnothing$

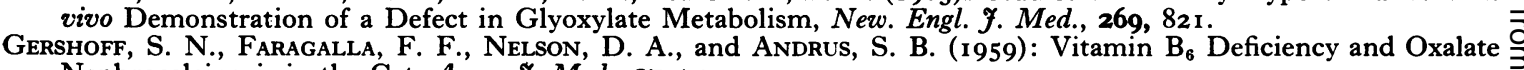
Nephrocalcinosis in the Cat, Amer. F. Med., 27, 72.

Gill, W. B., Finlayson, B., and Vermeulen, C. W. (1959): Prevention of Urinary Calculi in Rats by Adding Calcium to the Diet: Experimental Urolithiasis XVI, f. Urol. (Baltimore), 82, 256.

Gordan, E. E., and SHEPS, S. G. (1957): Effect of Acetazoleamide on Citrate Excretion and Formation of Renal Calculi, New Engl. F. Med., 256, 1215.

Hammarsten, G. (1956) In 'Etiologic Factors in Renal Lithiasis' p. 96., ed. by A. J. Butt, Springfield, Illinois: Charles C Thomas.

HARRISON, A. R. (1959): Some Results of Metabolic Investigations in Cases of Renal Stone, Brit. F. Urol., 31, 398.

Henneman, P. H., Benedict, P. H., Forbes, A. P., and Dudley, H. R. (1958): Idiopathic Hypercalciuria, New Engl. F. Med., 259, 802.

Hodgkinson, A. (1958): The Urinary Excretion of Oxalic Acid in Nephrolithiasis, Proc. roy. Soc. Med., 51, 44.

- (1962): Citric Acid Excretion in Normal Adults and in Patients with Renal Calculus, Clin. Sci., 23, 203. (1963): The Relation Between Citric Acid and Calcium Metabolism with Particular Reference to Primary $D$ Hyperparathyroidism and Idiopathic Hypercalciuria, Ibid., 24, 167. Pyrah, L. N. (1962): Hypercalciuria in Relation to Renal Calculi. Symp. Int. sur la Lithiase Calcique. Vittel, 4, II, 23. , and,$(1958)$ : The Urinary Excretion of Calcium and Inorganic Phosphate in 344 Patients with Calcium Stone of Renal Origin, Brit. F. Surg., 46, ro.

Howard, J. E. (1962): Urinary Stone, Canad. med. Ass. F., 86, $100 \mathrm{r}$.

-, Thomas, W. C., Mukai, T., Johnston, R. A., and PAscoe, B. J. (1962): The Calcification of Cartilage by Urine, O and a Suggestion for Therapy in Patients with Certain Kinds of Calculi, Trans. Ass. Amer. Physcn., 75, 301 .

HunT, L. D., and KING, J. S. (1963): Ionic Calcium in the Urine of Stone Formers, Invest. Urol., I, 83 .

Johnson, R. G. (1959): Prevention and Dissolution of Calculi in Rats with Fluoroacetate and Citric Acid, F. Urol. (Baltimore), 82, 261 .

Lichtwitz, A., Parlier, R., De Seze, S., Hioco, D., and Miravet, L. (I961): L'effect hypocalciurique des sulfamides diuretiques, Sem. Hop. Paris, 44, 2350.

Litin, R. B., Diessner, G. R., and Keating, F. R. (I96I): Urinary Excretion of Calcium in Patients with Renal Lithiasis, F. Urol. (Baltimore), 86, 17. 
Ludwig, G. D. (1963): Renal Calculi Associated with Primary Hyperoxaluria, Ann. N.Y. Acad. Sci., ro4, 621.

Mclaurin, A. W., Beisel, W. R., McCormick, G. J., Scaletta, R., and Herman, R. H. (I 96 I): Primary Hyperoxaluria, Ann. intern. Med., 55, 70.

Marshall, V. F., and Horwith, M. (1959): Oxalosis, f. Urol. (Baltimore), 82, 278.

Miller, G. H., Vermeulen, C. W., and Moore, J. D. (1958): Calcium Oxalate Solubility in Urine: Experimental Urolithiasis XIV., Ibid, 79, 607.

Mukai, T., and Howard, J. E. (1963): Some Observations on the Calcification of Rachitic Cartilage by Urine, Bull. Fohns Hopk. Hosp., II2, 279.

Murphy, B. T., and Pyrah, L. N. (1962): The Composition, Structure and Mechanisms of the Formation of Urinary Calculi, Brit. F. Urol., 34, 129.

Neuberg, C. (1916): Hydrotropic Qualities, Biochem. Z., 76, 107.

Neuman, W. F. (1962): Physico-chemical Aspects of Crystal Formation and Reabsorption in Human Urine: Conference on Renal Calculus Disease. Washington, D.C., p. 86.

Nordin, B. E. C. (1959): The Estimation of 'Free' Calcium in the Urine and its Relevance to Calculus Formation, Brit. F. Urol., 3I, 404.

- and Tribedi, K. (1962): Ionized Calcium in Normal and Stone-forming Urine, Lancet, r, 409.

Prien, E. L. (1963): Crystallographic Analysis of Urinary Calculi: A 23-year Survey Study, $\mathcal{F}$. Urol. (Baltimore), 89, 917.

-, Gershoff, S. N., and Andrus, S. B. (1962): Experimental Calcium Oxalate Stone Formation with Clinical Application. Proc. Symp. Internat. sur la Lithiase Calcique, Vittel., 4, II, 155.

—, and Walker, B. S. (1956): Salicylamide and Acetyl-salicylic Acid in Recurrent Urolithiasis, F. Amer. med. Ass., I60, 355 .

Pyrah, L. N., Anderson, C. K., Hodgkinson, A., and Zarembski, P. M. (1959): A Case of Oxalate Nephrocalcinosis and Primary Hyperoxaluria, Brit. F. Urol., 31, 235.

- RAPER, F. P., and Smith, I. B. (1956): The Use of Aluminium Hydroxide to Prevent Recurrent Renal Calculi, Ibid., 28, 231.

RaAflaub, J. (1960): On the Relationships Between the Total Content of Calcium and the Calcium Ion Concentration In the Urine, Helv. physiol. pharmacol. Acta, 18, C87.

Scott, W. W., Huggins, C., and Selman, B. C. (1943): Metabolism of Citric Acid in Urolithiasis, $\mathcal{F}$. Urol. (Baltimore) 50, 202.

Shorr, E., and CARTer, A. C. (1950): Aluminium Gels in the Management of Renal Phosphatic Calculi, $\mathcal{F}$. Amer. med. Ass., 144, 1549.

TAupitz, E., and GACA, A. (1962): Über die Zusammenhänge zwischen Urolithiasis und Citriturie, Urol. int. (Basel), $14,27$.

Thomas, W. C., Bird, E. D., and Tomita, A. (1963): Some Concepts Concerning the Genesis of Urinary Calculi

F. Urol. (Baltimore), 90, 521 . Renal Calculi, Trans. Ass. Amer. Phycns., 72, I81.

Vermeulen, C. W., Finlayson, B., and Chapman, W. (1957): Influence of Urinary Glucuronide on Solubility ofe, Calcium Phosphate and Stone Formation. Experimental Urolithiasis XII, Y. Urol. (Baltimore), 77, 685.

- Lyon, E. S., and Miller, G. H. (1958): Calcium Phosphate Solubility in Urine as Measured by a Precipitation Test: Experimental Urolithiasis XIII, Ibid., 79, 596.

,-- and GILL, W. B. (1964): Artificial Urinary Concretions, Invest. Urol. In the press.

-, Miller, G. H., and Chapman, W. H. (1956): On the State of Calcium in the Urine. Experimental Urolithiasis $\mathrm{X}, \boldsymbol{F}$. Urol. (Baltimore), 75, 592.

Walser, M. (I96I): Ion Association. (V) Dissociation Constants for Complexes of Citrate with Sodium, Potassium, Calcium and Magnesium Ions, $\mathcal{F}$. Phys. Chem., 65, 159.

Yarbro, C. L. (1958): Studies on the Solubility of Tricalcium Phosphate in Urine. I. Effect of Dilution, $\mathcal{F}$. Urol. (Baltimore), 80, 158.

Zarembski, P. M., and Hodgkinson, A. (1962): The Oxalic Acid Content of English Diets, Brit. F. Nutr., r6, 627.

- $-(1963)$ : The Renal Clearance of Oxalic Acid in Normal Subjects and in Patients with Primary Hyperoxaluria, Invest. Urol., $\mathbf{1}, 87$. 